\title{
ОБЪЕКТ ВСЕМИРНОГО КУЛЬТУРНОГО НАСЛЕДИЯ ГОРОД БОЛГАР И ЕГО ВКЛАД В ТЮРКСКУЮ ЦИВИЛИЗАЦИЮ
}

\author{
(C) 2019 г. А.Г. Ситдиков, С.Г. Бочаров
}

Город Болгар конца XIII - начала XIV в. становится одним из самых крупных производственных, торговых, культурных и культовых центров Золотой Орды и всей Европы. В золотоордынское время площадь его расширяется до 380 га. Он бурно застраивается каменными и кирпичными постройками, в том числе общественными зданиями: мечетями и банями. Они по праву считаются одними из самых величественных памятников зодчества периода Золотой Орды. Золотоордынский Болгар был значительным и важным городом. Благодаря возникновению и последовательному развитию городской цивилизации в Волго-Уральском регионе произошло становление тюрко-мусульманской цивилизации, определяющей облик современной Евразии.

Ключевые слова: археология, средневековый город Болгар, мировое культурное наследие, тюркская цивилизация

\section{Введение}

Во второй половине IX в. на Средней Волге возникает новое государство Волжская Булгария, во главе которого становится правитель по имени Алмыш [Греков, Калинин, 1948, с. 30]. Хозяйственноэкономическим фоном становления Болгарского государства было функционирование Великого Волжского пути и караванного пути в Хорезм как части Великого Шелкового пути, приведшего к резкому обогащению болгарской клановой аристократии, а также приток тюркского населения из районов Подонья, Приазовья и Северного Кавказа [Измайлов, 2012, c. 200-203].

Центрами государственных образований со своей административной структурой были города, на что указывает факт чеканки собственной монеты с именем своего правителя. Судя по данным археологии, самые ранние города, возникшие в Булгарии, - это целый ряд пунктов по берегам Волги и Камы от современных Чистополя до Старой Майны, а также бассейн р. Малый Черемшан и p. Свияги в средней его части [Смирнов, 1951, с. 158]. Здесь обнаружены самые ранние находки, позволяющие говорить о начальных этапах становления раннегородской структуры уже в начале X в. Вокруг городских пунктов - Болгара, Сувара, Биляра и других возникает и расширяется сельскохозяйственная округа [Халиков, 1973, c. 69-73].

\section{Обсуждение}

Практически с момента своего возникновения Булгария становится заметным явлением всемирной истории, объектом внимания арабо- 
персидских географов, русских летописцев, западноевропейских путешественников и торговцев. Это вполне объяснимо: самая северная в тогдашнем мире мусульманская страна - факт сам по себе незаурядный - быстро завоевала себе славу могущественной торговой державы [Измайлов, 2005, с. 551]. И не только благодаря своему удачному геополитическому положению. Основу экономического могущества страны, способствовавшего активной и равноправной международной торговле, составляли, в первую очередь, высокоразвитое сельское хозяйство (пашенное земледелие и животноводство) и ремесленное производство. Их продукция была рассчитана как на удовлетворение внутренних потребностей страны, так и на экспорт [Смирнов, 1951, с. 169].

Важным этапом в процессе объединения общества внутри государства было принятие ислама как государственной религии булгар. Процесс возвышения булгарского государства шел практически единовременно с проникновением ислама. По всей видимости, в начале X в. болгарская знать во главе с Алмышем принимают ислам, а с 920 года он становится государственной религией. Это подтверждается арабо-персидскими источниками и началом чеканки монет по мусульманским образцам [Измайлов, 2005, с. 550-556].

Сведений о месте Болгара и болгарских земель в системе евразийских связей довольно много [Фархутдинов, 1987, с. 9]. Для Х в. это «Рисале» Ибн Фадлана о контактах болгарского хана Алмуша с Арабским халифатом и рассказ венгерского Анонима о переселенцах из Биляра, занявших впоследствии важные государственные посты в администра- тивной системе Венгерского государства. Одиннадцатым веком можно датировать смутные сообщения скандинавских источников о «Вулгарии» как части русской Гардарики - «страны городов» [Смирнов, 1954, с. 302]. Далее идет сообщение персидского историка XII в. Бейхаки о посылке булгарским эмиром Ибрагимом денег и подарков в Хорасан на строительство мечетей в Себзеваре и Хосровджерде (1024/1025 г.). К ХІІ в. относится подробное описание Волжской Булгарии Абу-Хамидом ал-Гарнати, выходцем из Андалусии, и, наконец, к первой половине XIII в. - рассказ венгерского миссионера Юлиана о его путешествии в Булгарию в поисках своих сородичей, пребывающих в язычестве. Имеются, кроме того, многочисленные, к сожалению, фрагментарные известия о булгарах представителей классической арабской географической школы: Ибн-Русте, алБалхи, ал-Джайхани, ал-Истахри, алМасуди, Ибн-Хаукаля, ал-Мукаддаси, ал-Марвази, ал-Идриси и др., а также сведения древнерусских летописей, по которым можно в подробностях представить динамику булгарорусских взаимоотношений $\mathrm{X}$ - начала XIII в. [Измайлов, Исхаков, 2000, c. 59].

Контакты Булгарии с Востоком развивались по сухопутному пути из Средней Азии (Хорезма) через Южный Урал в Булгарию, который и являлся северным ответвлением Великого шелкового пути. Именно этим путем двигалось посольство багдадского халифа с Ибн-Фадланом, и определенно существовал регулярный торговый караванный путь [Петров, 1995, с. 32].

Связи с исламским миром, самым северным форпостом которого в «странах седьмого климата» (по тер- 
минологии арабо-персидской географии) была Волжская Булгария, выражались в существовавшей транзитной торговле через ее территорию (фактически Болгария являлась воротами для восточных товаров в Северную и Северо-Восточную Европу), а также в том, что в становлении многих ремесленных производств волжских булгар, особенно высокотехнологичных и художественных (стеклоделие, изготовление медной и бронзовой посуды и т.д.), принимали участие мастеpa, прибывшие в Поволжье из стран ислама, в первую очередь из Ирана и Анатолии [Измайлов, 2012, с. 235238]. В области идеологии и политики следует отметить двусторонность связей Булгарии с исламскими странами. Булгары не просто восприняли ислам от среднеазиатских проповедников и позже охотно приглашали гонимых на родине иранских и среднеазиатских наставников-суфиев, но и сами создали исламскую научную школу, давшую целый ряд ученых, многие из которых были широко известны на Востоке и даже занимали видные посты в администрации некоторых государств Ирана и Средней Азии [Измайлов, 2005, с. 552].

Взаимодействие булгар с ближними соседями - финно-угорскими народами лесной и кочевниками степной зоны Восточной Европы было частью формирования культурного пространства этого государства. Этот процесс взаимоотношений болгар с соседними народами начинался с торговых контактов и военных походов и завершился их включением в сферу влияния Булгарского государства. С одной стороны, это процесс постепенной адаптации пограничных или переселившихся на окраины Болгарии групп финно-угров, угров и тюрок в структуру государства: принятие ислама, распространение булгарской материальной культуры, включение в военно-политическую систему. С другой стороны - образование булгарских ремесленных центров на отдаленных от метрополии территориях финно-угорских племен и в степной зоне Поволжья [Смирнов, 1951, c. 203].

Образование в Евразии империи Чингиз-хана и его потомков привело к созданию «мировой державы», объединившей земли от Амура до Дуная и от Северного Ледовитого океана до Персидского залива. Междоусобная война крупнейших улусов и привела в 1269 г. к образованию самостоятельных государств, но даже тогда экономические и этнополитические связи объединяли их гораздо сильнее, чем спорадические пограничные конфликты [Измайлов, Исхаков, 2000, с. 53-55].

Практически сразу после монгольского завоевания продолжили активно действовать мировые торговые магистрали. Это, в первую очередь, Великий шелковый путь, который проходил через территорию Улуса Джучи от Ургенча до Азака и городов Крыма, через Сарай и торговый путь по Волге и Каспию, связывая Переднюю Азию с Северной Европой. В силу своего исключительно выгодного географического положения Улус Джучи стал средоточием целого ряда магистральных торговых путей, пронизывавших весь евразийский континент. Один из них - поволжский - связывал мусульманский Восток с Северной Европой и Балтикой. Второй - черноморско-волжский - соединял причерноморские города с нижневолжскими городами и далее со среднеазиатским ответвлением 
Ситдиков А.Г., Бочаров С.Г. Объект всемирного культурного наследия город Болгар и его вклад в тюркскую цивилизацию

Великого шелкового пути. Третий транскавказский - связывал страны Ближнего Востока с Юго-Восточной Европой [Петров, 1995, с. 34-36].

Важнейшей караванной дорогой для Золотой Орды служила магистраль, которая была северным ответвлением Великого шелкового пути и шла через города Восточного Туркестана, Семиречья, Хорезма в Поволжья, а оттуда - в Центральную Европу. Благодаря удачно сложившейся конъюнктуре в условиях войн и нестабильности на Среднем и Ближнем Востоке, вызванной монгольскими завоеваниями, вторжениями хорезмийцев и крестовыми походами, товарный поток из Китая хлынул в Европу через Поволжье [Федоров-Давыдов, 1998, с. 39-43]. Концентрация богатств, награбленных в завоеванных странах, и участие в мировой торговле колоссально обогатили аристократию Улуса Джучи и подталкивали ее к подчинению новых земель, к установлению контроля за балканским и малоазийским отрезками Великого шелкового пути. По этому знаменитому торговому пути, начинавшемуся в Китае и проходившему через Орду, шли многие необходимые для Западной Европы товары - пряности, шелк, хлопок, драгоценные камни, хлеб и рабы, а также меха и пушнина. Этот поток товаров, чрезвычайно ценившихся на рынках Европы, обогащал посредников и служил одной из основ благосостояния всех городов Дашт-и Кыпчака. С торговлей были связаны не только поступления в казну от торговых пошлин, но и благополучие многочисленной обслуги: караванщиков, проводников, охраны, владельцев караван-сараев, ремесленников и т.д. Кроме того, многие мастерские занимались изготовлением предме- тов на продажу и переработкой полуфабрикатов. Все они очень чутко реагировали на любые изменения торговой активности [Федоров-Давыдов, 1998, с. 53; Измайлов, Исхаков, 2000, c. 72].

Войдя в состав Улуса Джучи (Золотая Орда), булгарские земли с ее высоким экономическим потенциалом, с развитой системой государственного управления и исламом представляли значительный интерес для монгольских ханов с точки зрения экономической выгоды и легкости управления, что и объясняет их стремление обеспечить спокойствие на подвластной территории. Самым крупным и известным булгарским городом того времени был Болгар (рис. 1). Этот город, возникший еще в начале Х в., не отличался в домонгольский период большими размерами (примерно 12 га) и состоял из небольшой крепости и торгово-ремесленных пригородов, хотя и был важным экономическим центром [Смирнов, 1954, c. 315 ; Старостин и др., 1994, с. 9]. Настоящая его история начинается с 40-х гг. ХІІІ в., когда, вернувшись из западного похода и подавив восстание булгар, Бату сделал местом своей ставки район Нижнего Прикамья (рис. 2). Существует предположение, что именно Болгар стал первой столицей Улуса Джучи и местом, где началась чеканка татарских монет - серебряных и медных дирхемов с именем багдадского халифа Насир-лид-Дина [Федоров-Давыдов, 2003, с. 10-12]. Этот район имел стратегическое значение, так как позволял в начальный период формирования империи контролировать две самые важные области - Русь и Булгарию. Постепенно, благодаря богатым традициям высокоразвитого сельского хозяйства и ре- 


\section{ҚАЗАҚСТАН АРХЕОЛОГИЯСЫ № 4 (6) 2019}

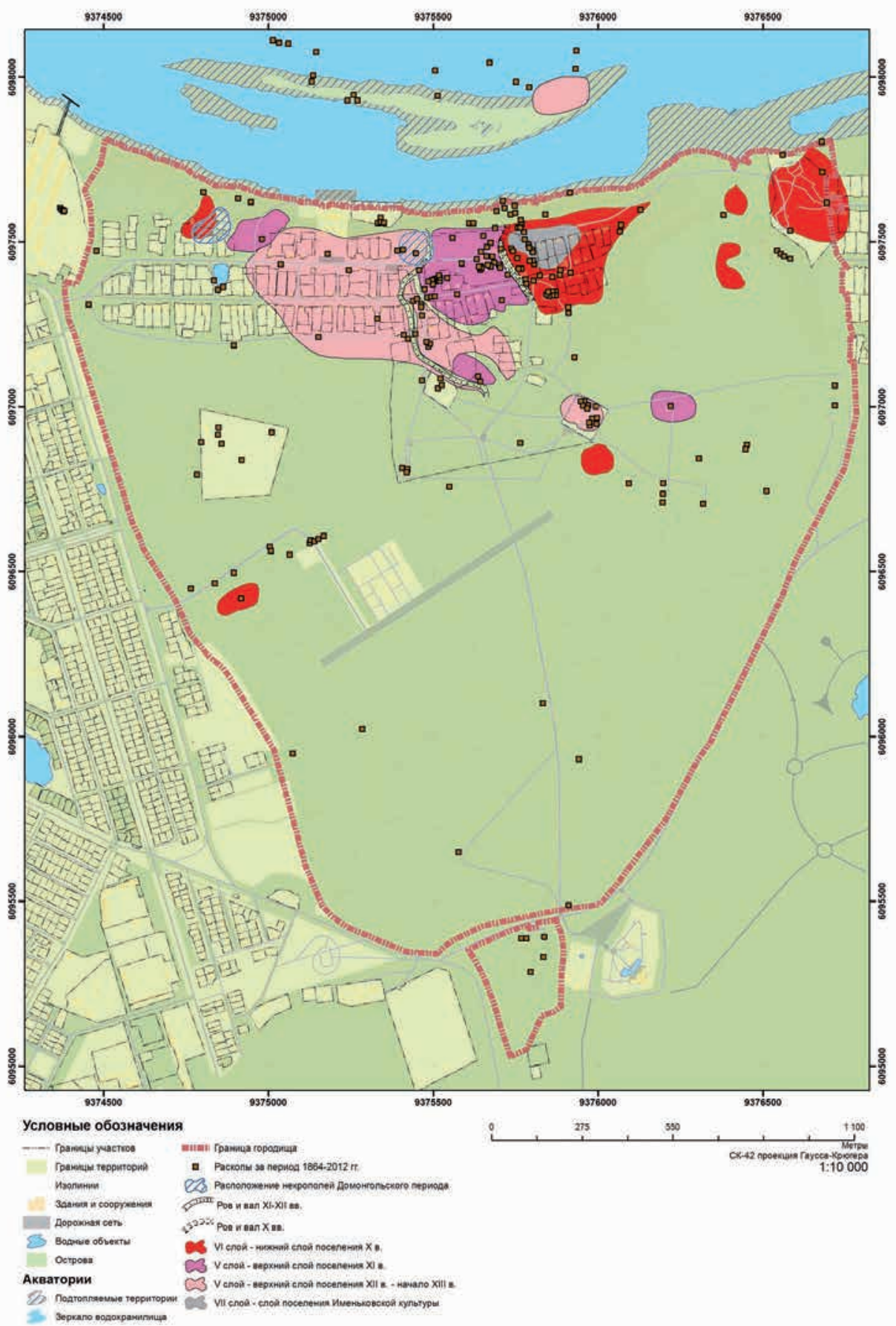

Рис. 1. Карта расположения культурных слоёв и некрополей объекта Всемирного культурного наследия ЮНЕСКО - город Болгар периода Волжской Булгарии (по: [Атлас Великий Болгар, 2013])

Fig. 1. Map of the location of cultural layers and necropolises of the UNESCO World Heritage Site - The City of Bolgar during The Volga's Bulgaria period (by: [Atlas Great Bolgar, 2013]) 
Ситдиков А.Г., Бочаров С.Г. Объект всемирного культурного наследия город Болгар и его вклад в тюркскую цивилизацию

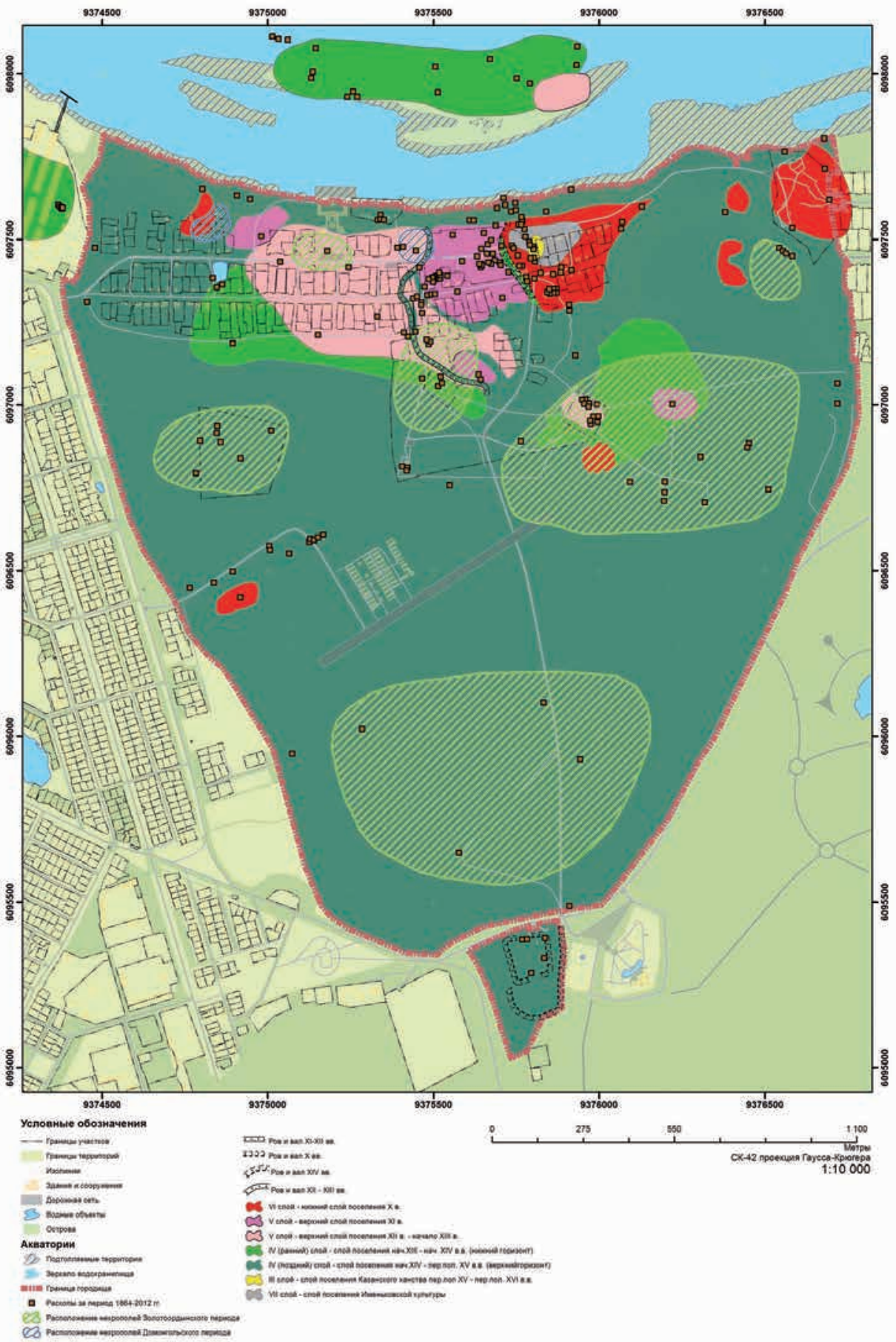

Рис. 2. Карта расположения культурных слоёв и некрополей объекта Всемирного культурного наследия ЮНЕСКО - город Болгар периода Золотой Орды (по: [Атлас Великий Болгар, 2013])

Fig. 2. Map of the location of cultural layers and necropolises of the UNESCO World Heritage Site - The City of Bolgar during The Golden Horde period (by: [Atlas Great Bolgar, 2013]) 
меслу, удалось во многом преодолеть последствия завоевания и добиться возрождения региона.

\section{Заключение}

Город Болгар конца XIII - начала XIV в. становится одним из самых крупных производственных, торговых, культурных и культовых центров Золотой Орды и всей Европы. В золотоордынское время площадь его расширяется до 380 га, а население доходило до 20 тыс. человек. Он бурно застраивается каменными и кирпичными постройками, в том числе общественными зданиями: мечетями [Бочаров, Ситдиков, 2014, с. 533] и банями [Воскресенский и др., 1967, c. 279]. Они по праву считаются одними из самых величественных памятников зодчества периода Золотой Орды. Золотоордынский Болгар был значительным и важным городом. Улицы были покрыты мостовыми. Благоустройству города служили водопроводные и дренажно-ряжевые системы. Продолжая ранние булгарские традиции, ремесленники изготавливали предметы широко известные во всем цивилизованном мире: кожаные изделия, оружие, украшения. Выгодное географическое положение на пересечении речных и сухопутных путей делали Болгар важным перевалочным пунктом мировой торговли [Фёдоров-Давыдов, 1998, с. 46]. Именно благодаря возникновению и последовательному развитию городской цивилизации в Волго-Уральском регионе произошло становление тюрко-мусульманской цивилизации, определяющей облик современной Евразии.

\section{ЛИТЕРАТУРА}

1. Атлас Великий Болгар. М.; Казань: Изд-во Феория, 2013. 404 с.

2. Бочаров С.Г., Ситдиков А.Г. Центральная мечеть города Болгар в золотоордынский период // Древние и средневековые государства на территории Казахстана: сб. науч. ст., посвящ. 90-летию выдающегося ученого-археолога Кималя Акишева. Алматы: Институт археологии им. А.Х. Маргулана, 2014. С. 532-548.

3. Воскресенский А.С., Смирнов А.П., Хлебникова Т.А. Новое об архитектуре волжских болгар // СА. 1967. № 4. С. 274-285.

4. Греков Б.Д., Калинин Н.Ф. Булгарское государство до монгольского завоевания // Материалы по истории Татарии. Казань: Татгосиздат, 1948. С. 36-42.

5. Измайлов И.Л. Ислам и мусульманская культура в Волжской Болгарии // История татар с древнейших времен в 7-ми томах. Т. II. Волжская Булгария и Великая степь. Казань: Изд. Рух ИЛ, 2005. С. 549-556.

6. Измайлов И.Л. Становление Волжской Булгарии: от племени к государству // Studia Slavica et Balcanica Petropolitana. 2012. № 2 (12). С. 217-242.

7. Измайлов И.Л., Исхаков Д.М. Этнополитическая история татар в VI - первой четверти XV в. Казань: Изд-во «Иман», 2000. 136 с.

8. Петров А.М. Великий шелковый путь (О самом простом, но малоизвестном). М.: Восточная литература, 1995. 127 с.

9. Смирнов А.П. Волжские булгары // Труды ГИМ. 1951. Вып. ХІХ. С. 154-223.

10. Смирнов А.П. Основные этапы города Болгара и его историческая топография // МИА. 1954. № 42. С. 298-320.

11. Старостин П.Н., Хлебникова Т.А., Шарифуллин Р.Ф. Археологическое изучение Болгара // Город Болгар и его округа. Тез док научной конференции. Болгар: БГИАЗ, 1994. С. 8-10. 
Ситдиков А.Г., Бочаров С.Г. Объект всемирного культурного наследия город Болгар и его вклад в тюркскую цивилизацию

12. Фахрутдинов Р.Г. Болгар в письменных источниках // Город Болгар. Очерки истории и культуры. М.: Наука, 1987. С. 9-33.

13. Федоров-Давыдов Г.А. Торговля нижневолжских городов Золотой Орды // Материалы и исследования по археологии Поволжья. Йошкар-Ола: Изд. МарГУ, 1998. C. $38-59$.

14. Федоров-Давыдов Г.А. Денежное дело Золотой Орды. М.: «Палеограф», 2003. $344 \mathrm{c}$.

15. Халиков А.Х. О столице домонгольской Булгарии // СА. 1973. № 3. С. 65-74.

\section{Сведения об авторах:}

Ситдиков Айрат Габитович - доктор исторических наук, директор, Институт археологии им. А.Х. Халикова Академии наук Республики Татарстан, декан Высшей школы Исторических наук и Всемирного культурного наследия, Институт международных отношений, Казанский федеральный университет (г. Казань, Россия), sitdikova@mail.ru

Бочаров Сергей Геннадиевич - кандидат исторических наук, учёный секретарь, доцент, Институт археологии им. А.Х. Халикова Академии наук Республики Татарстан, Казанский федеральный университет (г. Казань, Россия), sgbotcharov@mail.ru

\section{БОЛГАР ҚАЛАСЫ ӘЛЕМДІК МӘДЕНИ МҰРА НЫСАНЫ ЖӘНЕ ОНЫҢ ТУРКІ ӨРКЕНИЕТІНЕ ҚОСҚАН ҮЛЕСІ}

\section{А.Г. Ситдиков, С.Г. Бочаров}

Болгар қаласы XIII аяғы - XIV ғ. басында Алтын Орданың және бүкіл Еуропаның ең ірі өндірістік, сауда, мәдениет және культтік орталығына айналады. Алтын Орда дәуірінде оның аумағы 380 га дейін кеңейеді. Онда өте қарқынды түрде тас және кірпіш құрылыстар, оның ішінде қоғамдық орындар: мешіттер мен моншалар салынады. Олар заңды түрде Алтын Орда кезеңінің сәулет ескерткіштерінің маңыздыларының бірі болып табылады. Алтынордалық Болгар айтарлықтай және маңызды қала болды. Қала өркениетінің қалыптасуы мен жүйелі түрде дамуының арқасында Еділ-Жайық өңірінде қазіргі Еуразияның келбетін анықтайтын түркімұсылман өркениетінің қалыптасуы орын алды.

Түйін сөздер: археология, ортағасырлық Болгар қаласы, әлемдік мәдени мұра, түркі өркениеті

\section{MONUMENT OF THE WORLD CULTURAL HERITAGE CITY OF BOLGAR AND ITS CONTRIBUTION TO TURKIC CIVILIZATION}

\section{A.G. Sitdikov, S.G. Bocharov}

The city of Bolgar at the end of XIII - beginning of XIV century becomes one of the largest industrial, commercial, cultural and religious centers of the Golden Horde and the whole of Europe. In the Golden Horde time, its area expanded to 380 hectares. It is rapidly built up with stone and brick buildings, including public obdjects: mosques and baths. They are considered to be among the most magnificent monuments of Tatar architecture of the Golden Horde period. The Golden Horde Bolgar was a significant and important city. Due to emergence and consistent development of urban civilization in the Volga-Ural region, formation of Turkic Civilization took place, which largely determined the image of modern Eurasia.

Keywords: Archaeology, Medieval city of Bolgar, World Cultural Heritage, Turkic Civilization 


\section{REFERENCES} (in Russian).

1. Atlas Velikii Bolgar. 2013. (Atlas Great Bolgar). Moscow, Kazan: Feoria Publ.

2. Bocharov, S. G., Sitdikov, A. G. 2014. In Drevnie i srednevekovyie gosudarstva na territorii Kazahstana (Ancient and medieval states in Kazakhstan). Almaty: A.Kh. Margulan Institute of Archeology, 532-548 (in Russian).

3. Voskresenskiy, A. S., Smirnov, A. P., Hlebnikova, T. A. 1967. In Sovetskaya arheologiya (Soviet archeology), 4, 274-285 (in Russian).

4. Grekov, B. D., Kalinin, N. F. 1948. Materialyi po istorii Tatarii (Materials on the history of Tatarstan), 36-42 (in Russian).

5. Izmaylov, I. L. 2005. In Istoriya tatar s drevneyshih vremen $v 7$ tomah (The history of the Tatars from ancient times in 7 volumes), II, 549-556 (in Russian). (in Russian).

6. Izmaylov, I. L. 2012 In Studia Slavica et Balcanica Petropolitana, 2 (12), 217-242

7. Izmaylov, I. L., Ishakov, D. M. 2000. Etnopoliticheskaya istoriya tatar v VI-pervoy chetverti $X V v v$. (Ethnopolitical history of the Tatars in the VI-first quarter of the $X V$ centuries). Kazan: «Iman» Publ. (in Russian).

8. Petrov, A. M. 1995. Velikiy shelkovyiy put (O samom prostom, no maloizvestnom) (The Great Silk Road (On the simplest, but little known)). Moscow: "Vostochnaya literatura» Publ. (in Russian).

9. Smirnov, A. P. 1951. In Trudy Gosudarstvennogo istoricheskogo muzeya (Proceedings of the State Historical Museum), XIX, 154-223 (in Russian).

10. Smirnov, A. P. 1954. In Materialyi i issledovaniya po arheologii SSSR (Materials and research on archeology of the USSR), 42, 320 (in Russian).

11. Starostin, P. N., Hlebnikova, T. A., Sharifullin, R. F. 1994. In Gorod Bolgar i ego okruga (The city of Bulgar and its district), 8-10 (in Russian).

12. Fahrutdinov, R. G. 1987. In Gorod Bolgar. Ocherki istorii i kulturyi (City of Bulgar. Essays on History and Culture), 9-33 (in Russian).

13. Fedorov-Davyidov, G. A. 1998. In Materialy i issledovaniya po arheologii Povolzhya (Materials and research on archeology of the Volga region), 38-59 (in Russian).

14. Fedorov-Davyidov, G. A. 2003. Denezhnoe delo Zolotoy Ordy (Money business of the Golden Horde). Moscow: «Paleograf» Publ. (in Russian). (in Russian).

15. Khalikov, A. Kh. 1973. In Sovetskaya arheologiya (Soviet archeology), 3, 65-74

\section{About the Authors:}

Sitdikov Ayrat. Doctor of Historical Sciences, Head, Institute of Archaeology named after A.Kh. Khalikov of the Academy of Sciences of the Republic of Tatarstan, Dean of the Higher School of Historical Sciences and World Cultural Heritage, Institute of International Relations, Kazan Federal University, Kazan, Russia; sitdikov_a@mail.ru

Bocharov Sergei. Candidate of Historical Sciences, Academic Secretary, Institute of Archaeology named after A.Kh. Khalikov of the Academy of Sciences of the Republic of Tatarstan, Associate professor, Department of History of Tatarstan, Archaeology and Ethnology, Kazan Federal University, Kazan, Russia; sgbotcharov@mail.ru

\footnotetext{
Мүдделер қақтығысы туралы ақпаратты ашу. Авторлар мүдделер қақтығысының жоқтығын мәлімдейді. / Раскрытие информации о конфликте интересов. Авторы заявляют об отсутствии конфликта интересов. / Disclosure of conflict of interest information. The authors claims no conflict of interest.

Мақала туралы акпарат / Информация о статье / Information about the article. Редакцияға түсті / Поступила в редакцию / Entered the editorial office: 14.09.2019. Рецензенттер мақұлдаған / Одобрено рецензентами / Approved by reviewers: 23.09.2019.

Жариялауға қабылданды / Принята к публикации / Accepted for publication: 30.09.2019.
} 